\title{
The Scientific Career of Frederik Hendrik Kreuger
}

\author{
P. H. F. Morshuis \\ High Voltage Laboratory, Delft University of \\ Technology, Delft, The Netherlands
}

Research is a gamble. But the only risk greater than doing research is not doing it.

F. H. Kreuger

$\mathrm{F}$ REDERIK Hendrik Kreuger's first encounter with I the outside world was in Amsterdam, on May 14, 1928. After attending high school the young Kreuger went to Delft to study Electrical Engineering at the TECHNISCHE HOGESCHOOL. In 1954 after having obtained his diploma, the young engineer took off for Sweden. He could not foresee at that time that he would return to the HV laboratory at the University at different stages in his career.

At the HV laboratories of ASEA in Västeràs and in Ludvika, Kreuger took his first steps in the field. His very first publication [1] dates from the year that he was a research engineer in Sweden. In this Dutch paper he describes the use of an anti-corona lacquer for $\mathrm{HV}$ machines. So, from the very start, partial discharges were to Kreuger a major issue. In this first paper we can already recognize Kreuger's clear writing style: to the point, and no unnecessary details and formulas. Readability has always been very important for him and many years later when he was a professor he demanded from his students to write clear reports. An often recurring situation is the following. Kreuger (looking at the student's report): "This figure is unreadable!" Student (getting a bit nervous): "But there is a description along the figure axes ...". Kreuger: "You mean these stains? But how can you do that to the poor reader, these small letters! You must have done that with a computer, so unclear. When I was young we learned to make technical drawings by hand!"

After a short stay in Rugby, England in the HV laboratory of British Thomson Houston, Kreuger returned to the Netherlands in 1956. At the N. V. Nederlandse Kabelfabrieken (NKF) in Delft he took a position as a research engineer in the $\mathrm{HV}$ research laboratory. Here his research on partial discharges began to flourish and the basis for his well-known book on detection of partial discharges was laid.

Having met his old professor Heyn again, it was decided that a PhD thesis would be written on the work Kreuger had done on detection and location of partial discharges in cables. At the CIGRE International Conference on Large High Tension Electric Systems in 1958 he was for the first time present on the international stage with his paper Detection de décharges internes. This was the start of a long succession of contributions especially in study committee 15 (Insulating Materials) and 21 (Cables). It must be stated that SC21 always has been Kreuger's favorite. One of the reasons probably is his denial of the importance of 'materials'. At the opening of a HV laboratory in Sweden many years later he would state that "Materials do not exist". Kreuger has never been short of direct, bold statements, and this is a good example. What he means is that we should not focus on the (insulating) material, but on the complete technical construction with all its interfaces and flaws.

In 1961 Kreuger graduated from the Technische Hogeschool Delft on Detection and location of discharges - in particular in plastic-insulated $H V$ cables. Based on his $\mathrm{PhD}$ thesis, his pioneering book on Discharge detection in $H V$ equipment [7] appeared in 1964. Even a Japanese translation appeared.

Kreuger made his way up at NKF and in 1969 he became head of the HIGH Voltage REsearch LABORATORY and in 1976 NKF Kabel promoted him to technical director. Among other things, this meant that he had to be skilled in management tactics. Kreuger made a detailed study on this topic and published yet another book: Management and Mismanagement in Research [21]. One of the one-liners in this book is particularly interesting in times of declining research budgets:

"The cost of research is the price of staying in business." 


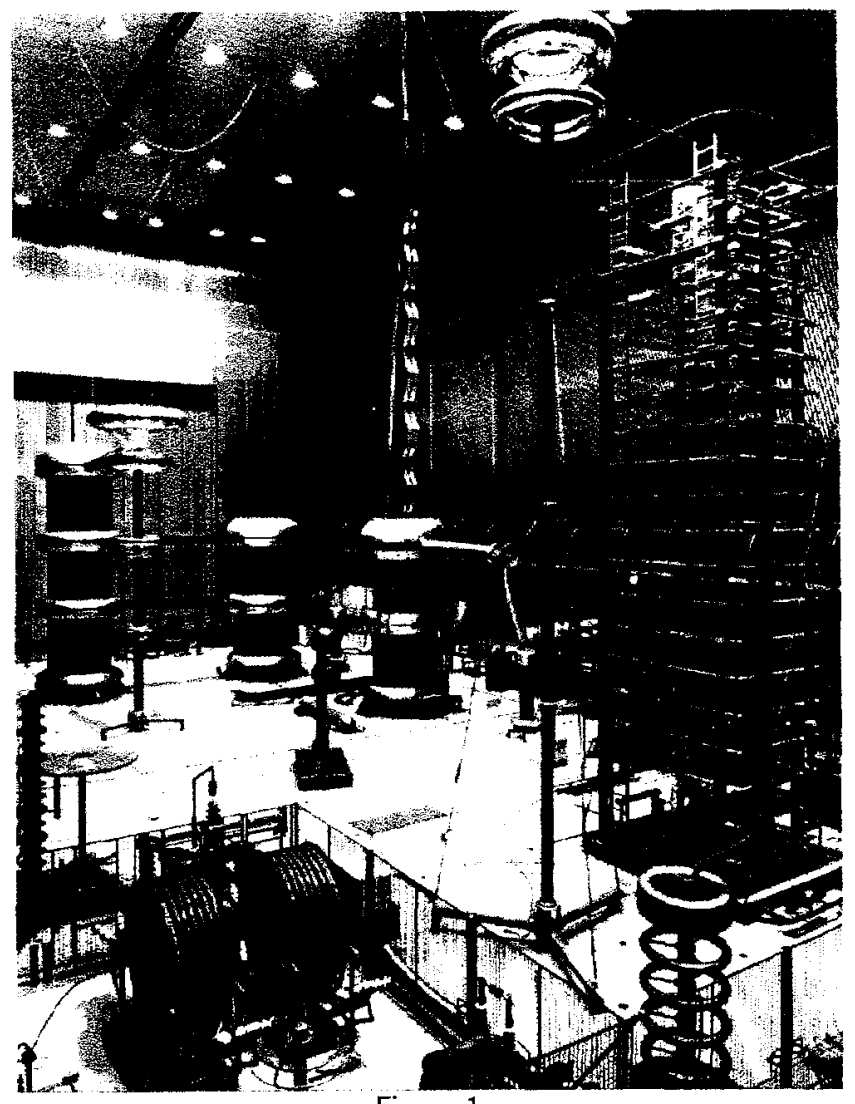

Figure 1 .

View of some of the test facilities in the HV laboratory at Delft University.

On the international forum Kreuger displayed his management skills by chairing the CIGRE working group Discharges in Cables for many years (1963-1974).

In 1985 Kreuger returned to the $\mathrm{HV}$ laboratory at the University, this time as a professor, and now for good. The first research project that was initiated was a $\mathrm{PhD}$ study on Computer aided recognition of partial discharges. Pioneering work was done on the use of computers for statistical analysis of partial discharge data. In 1991 the PhD thesis of Edward Gulski appeared and this subject is now one of the pillars of the high voltage group.

At the same time Kreuger was still involved with NKF and very active when a new type of belted cable was developed. It was found that the application of a swelling tape in three-phase belted cables increased the voltage life considerably and unexpectedly. To study the physics behind this phenomenon Kreuger's second $\mathrm{PhD}$ student started a study on the aging process in voids in polymers. Ultra-wide band measurements, both optical and electrical, were introduced and in 1993 Peter Morshuis successfully defended his $\mathrm{PhD}$ thesis on that topic.

In making a scientific biography of professor Kreuger one should not forget his non-scientific side. Music, and in particular Hungarian and gypsy music are inextricably connected to Kreuger. Never will we forget the open day at the University when he and his SIPERKOV ensemble sat down in a large Faraday cage. In the darkened high voltage laboratory they played the stars from heaven while (artificial) lightning struck the cage over and over again.

Early in 1993 yet another PhD student graduated, in this case on a topic with no interference from discharges. Jing Tao had studied the fundamentals of surface charging of spacers for GIS. Some of the results of this project can be found in the book Kreuger was to write later on Industrial High DC Voltage.

At the end of the 80's alarming sounds started to reach Kreuger's ears: the number of new power engineers lagged way behind the number needed in industry. With a couple of other concerned captains of industry, he initiated the van Staveren Stichting with the objective to promote power engineering at middle and high schools. Exhibitions were organized, special editions of popular magazines appeared and gradually the number of power engineers increased [28,34]. There is no doubt that Kreuger's efforts have contributed greatly to this increase.

In 1991 two new PhD students started on 'Non-energy $\mathrm{dc}$ ' and on 'Recognition of partial discharges in $\mathrm{HV}$ equipment'. The dc project has now become one of the major research projects and resulted in a better understanding of aging processes and partial discharges in dc apparatus. Another result of the work of Udo Fromm is the production of a partial discharge detector with diagnostic software especially developed for dc. Andrej Krivda has made an extensive study of pattern recognition methods and their suitability for classification of partial discharges.

The work of Kreuger's last PhD student, Marc Jeroense, is the proof of his growing enthusiasm for dc. In the Netherlands, the submarine cable links to Scandinavia are a topic of growing interest and led Kreuger to start a project on HVDC cables. The culmination of Kreuger's enthusiasm can be found in his recently published book Industrial High DC Voltage [90].

Before concluding this biography it only remains to say that on behalf of my colleagues of the HV Laboratory I wish professor Kreuger a long, healthy and active retirement. During all of his professional career, professor Kreuger has been involved in research. Therefore I would like to end with his statement:

"Research is a gamble. But the only risk greater than doing research is not doing it." 


\section{REFERENCES}

[1] F. H. Kreuger, "Coronawerende Lak Bij Hoogspanningsmachines", De Ingenieur, E. Electrotechniek 11, Vol. 67, No. 39, pp. 107-110, 1955.

[2] F. H. Kreuger, "Detection of Internal Discharges Particularly in HV Cables", CIGRE International Conference on Large High Tension ElectricSystems, Paris, paper 204, pp. 1-20, 1958.

[3] F. H. Kreuger, "Isolatie van Oliedrukkabels Proeven Aan Kabelmodelen", Electro-techniek, Vol. 38, no. 25, pp. 623-646, 1960.

[4] F. H. Kreuger, "Variables Affecting the Dielectric Strength of Oil-impregnated Cables", CIGRE International Conference on Large High Tension ElectricSystems, Paris, paper 206, pp. 1-19, 1962.

[5] F. H. Kreuger, "Scanning of Screened Plastic Cores for Discharges", IEE Proceedings, Vol. 109, Part A, Supp. 3, pp. 129-133, 1962.

[6] F. H. Kreuger, "Detectie van Ontladingen in Diëlektrica", Elektrotechniek, Vol. 40, no. 3, pp56-60, 1962.

[7] Kreuger, F. H., Detection of discharges in $\mathrm{HV}$ equipment. Temple Press Books, London, 1964.

[8] F. H. Kreuger, "Ontwikkeling van Garnituren Voor $150 \mathrm{Kv}$ Oliedrukkabel", De Ingenieur, no. 47, pp. 115-128, 1965.

[9] F. H. Kreuger, "Discharge Detection Methods Recommended for Discharge Tests on Cables", CIGRE International Conference on Large High TensionElectric Systems, Paris, paper 209, pp. 1-30, 1966.

[10] F. H. Kreuger, "Accessories for Plastic Insulated HV Cable", International Conference on Large High Tension Electric Systems, Paris, paper 201, pp. 1-17, 1966.

[11] F. H. Kreuger, "Calibration Recommended Means for Calibrating and Checking Discharge Detection Circuits", CIGRE International Conference on Large High Tension Electric Systems, Paris, paper 21-01, 1968.

[12] F. H. Kreuger, "Endurance Tests with Polyethylene Insulated Cables", CIGRE International Conference on Large High Tension ElectricSystems, Paris, paper 21-02, 1968.

[13] F. H. Kreuger, "Determination of the Internal Discharge Resistance of Dielectric Materials", IEEE Summer Power Meeting, Chicago, 1968.

[14] F. H. Kreuger, "Determination of the Internal Discharge Resistance of Dielectric Materials", IEEE Transactions on EI, Vol. EI-3, No. 4, pp. 108-114, 1968.
[15] F. H. Kreuger, "Durée de vie et décharges internes dans les isolations plastiques", Revue Générale de l'Electricité, Vol. 77, No. 5, pp. 540-542, 1968.

[16] F. H. Kreuger and J. M. Oudin, "Different Types of Aging in Plastic Insulated Cable", IEEE Winter Power Meeting, New York, 1969.

[17] F. H. Kreuger, " $150 \mathrm{kV}$ kabelverbindingen voor groot vermogen", Electrotechniek, Vol. 47, nr. 20, pp. 459-473, 1969.

[18] F. H. Kreuger and M. C. Lelie, "The Mean or Maximum Stress Theory: Possible Solution of an old Dilemma", IEEE Transactions on PAS, Vol. PAS88, no. 4, pp. 330-334, 1969.

[19] F. H. Kreuger, "Polyethylene Insulated Cable with Diffused Gas", CIGRE International Conference on Large High Tension Electric Systems, Paris, paper 21-02, 1970.

[20] F. H. Kreuger and P. A. C. Bentvelsen, "Breakdown Phenomena in Polyethylene Insulated Cable”, CIGRE International Conference on Large High Tension Electric Systems, Paris, paper 21$05,1972$.

[21] F. H. Kreuger, Management and Mismanagement in Research", published by NKF, Delft, 1972.

[22] F. H. Kreuger, "Air-spaced Dielectrics in Multipair Symmetric Cables", 23rd International Wire and Cable Symposium, Atlantic City, 1973.

[23] F. H. Kreuger and G. C. van Deventer, "Spacer Cable", CIGRE International Conference on Large HV Electric Systems, Paris, paper 21-04, 1974.

[24] F. H. Kreuger, H. L. Gorissen, and J. F. Kooy, "A New Type of Longitudinally Waterproof Telephone Cable", 24 th International Wire andCable Symposium, Cherry Hill, New Yersey, pp. 1-4, 1975.

[25] F. H. Kreuger and P. A. C. Bentvelsen, "Plastic Insulated Cable with Voltage Dependent Core Screen", CIGRE International Conference on Large HV Electric Systems, Paris, paper 21-02, pp. 1-4, 1978.

[26] F. H. Kreuger and A. M. F. J. van de Laar, "Silane Crosslinked Medium Voltage Cable", Proceedings CIRED 1985, pp. 231-233.

[27] F. H. Kreuger, "Hoogspanning van Natuur Naar Techniek", Elektrotechniek 64, nr. 5, 1986.

[28] F. H. Kreuger, "Twee Stichtingen Werken Aan Het Herstel van Sterkstroomonderwijs", Elektrotechniek 64, nr. 8, 1986.

[29] F. H. Kreuger, "Kabels", Elektrotrechniek 64, nr. $12,1986$. 
[30] F. H. Kreuger, "Partial Discharge Measurements", CIGRE symposium 1987, special report nr. $700-$ 05, 1987.

[31] F. H. Kreuger, Sonneveld, W. A., van Aalst and R. J., "Three Phase Detection", CIGRE symposium 1987, paper nr. 700-05, 1987.

[32] F. H. Kreuger and van Aalst, "Sic: Cable System with Built-in Terminations", CIRED 1987, Liège, paper nr. d. 08, 1987.

[33] F. H. Kreuger, "To know them is to Love Them", IEEE Spectrum 1987.

[34] F. H. Kreuger, "The Recruitment of Power Engineers, or the Recruitment of Power Students?", Power Engineering Journal, May, 1987.

[35] F. H. Kreuger, "Latest Developments of Methods for the Surveillance of Electrical Apparatus in $\mathrm{HV}$ Power Networks", Electra, nr. 14, 1987.

[36] F. H. Kreuger and E. Gulski, "Simultane Erfassung und Verarbeitung von TE-Kenngrößen zur Beurteilung elektrischer Isolierungen", Technisches Messen, Vol. 1, pp. 17-22, 1988.

[37] F. H. Kreuger, "Inception of Corona", IEEE Electrical Insulation Magazine, Vol. 4, no. 1, 1988.

[38] F. H. Kreuger, P. H. F. Morshuis and W. A. Sonneveld, "Optical Detection of Surface Discharges", IEEE Transactions on EI, Vol. 23, pp. 447-449, 1988 .

[39] F. H. Kreuger and E. Gulski, "Automatisering van De Waarneming van Partiële Ontladingen", Elektrotechniek 66, nr. 6, 1988.

[40] F. H. Kreuger, P. H. F. Morshuis and A. F. M. van de Laar, "A New Cable Phenomenon", IEEE Electrical Insulation Magazine, Vol. 4, nr. 4, 1988.

[41] P. H. F. Morshuis, F. H. Kreuger and P. P. Leufkens, "The Effect of Different Types of Inclusions on Pe Cable Life", IEEE Transactions on EI, Vol. 23, 1988.

[42] F. H. Kreuger and E. Gulski, "Digitale Analyze van Partiële Ontladingen", Elektrotechniek 66, nr. $11,1988$.

[43] F. H. Kreuger, P. H. F. Morshuis, and A. M. F. van de Laar, "A Newconcept for Medium-voltage Cables", IEEE Transactions on EI, Vol. 24, pp. 1063-1070, 1989.

[44] F. H. Kreuger and S. Shihab, "Partial Discharge Measurement on Three-core Belted Power Cables", IEEE Transactions on Power Delivery, Vol. 4, pp. 927-931, 1989.
[45] E. F. Steennis, Water treeing. The behavior of water trees, in extruded cable insulation, $\mathrm{PhD}$-thesis Delft University of Technology, KEMA, Arnhem, Promotor: Prof. dr. ir. F. H. Kreuger, ISBN 90353-1020-9, 1989.

[46] E. Gulski and F. H. Kreuger, "Digital Computer System for Measurement Of, Partial Discharges in Insulation Structures", 3 rd International Conference on Conduction and Breakdown in Solid Dielectrics. Trondheim, pp. 582-587., 1989.

[47] E. Harkink, F. H. Kreuger and P. H. F. Morshuis, "Partial Discharges in 3-Core Belted Power Cables", IEEE Transactions on EI, Vol. 24, no. 4, pp. 591-598., 1989.

[48] P. H. F. Morshuis and F. H. Kreuger, "Discharge Phenomena in Voids Filled with Fibrous Materials", 3rd Int. Conf. on Conduction and Breakdown in Solid Dielectrics, Trondheim, pp. 117-121, 1989.

[49] E. Gulski and F. H. Kreuger, "Digital Computer System for Measurement of Partial Discharges in Insulation Structures", 3rd Int. Conf. on Conduction and Breakdown in Solid Dielectrics, Trondheim, pp. 582-586, 1989.

[50] F. H. Kreuger, Partial discharge detection in $H V$ equipment, Butterworths and Co., London, 1989.

[51] F. H. Kreuger and E. Gulski, "Automatisiertes Meßsystem zur Erfassung von Teilentladungskenngrössen für Beurteilung Elektrischer Isolierungen", Technisches Messen 56, Vol. 3, pp. 124-129, 1989.

[52] P. P. Leufkens and F. H. Kreuger, "Solid Aluminum Conductor for HV Extruded Cables", 11th IEEE PES, T\&D Conference, New Orleans, 1989.

[53] P. H. F. Morshuis and F. H. Kreuger, "Klassifizierung Der Schädlichkeit Verschiedener Einschlüsse Hinsichtlich Der Lebensdauer von PEKabeln", etzArchiv, Vol. 11, pp. 231-234, 1989.

[54] P. H. F. Morshuis and F. H. Kreuger, "Transition from Streamer to Townsend Mechanisms in Dielectric Voids", J. Phys. D: Appl. Phys., Vol. 23, pp. 1562-1568, 1990.

[55] E. Gulski and F. H. Kreuger, "Computer-aided Recognition of Discharge Sources", 1990 International workshop on methods for partial discharge measurement and their traceability., Como, 4-6 September, 1990.

[56] E. Gulski and F. H. Kreuger, "Computer-aided Analysis of Discharge Patterns", J. Phys. D: Appl. Phys., Vol. 23, pp. 1569-1575., 1990. 
[57] E. Gulski, P. H. F. Morshuis and F. H. Kreuger, "Automized Recognition of Partial Discharges in Cavities", Japanese Journal of Applied Physics, Vol. 29, no. 7, pp. 1329-1335., 1990.

[58] T. Jing, P. H. F. Morshuis and F. H. Kreuger, "The Calibration of a Capacitive Probe for Surface Charge Measurements", Archiv für Elektrotechnik, Vol. 73, no. 5, pp. 337-341, 1990.

[59] F. H. Kreuger and P. H. F. Morshuis, "A New Concept for Media-voltage Cables. Improved Voltage Life of Belt-type Cables", IEEE Transactions on EI, Vol. 24, no. 6, pp. 63-1070, 1990.

[60] E. F. Steennis and F. H. Kreuger, "Water Treeing in Polyethylene Cables", IEEE Transactions on EI, Vol. 25, no. 5, pp. 989-1028, 1990.

[61] P. H. F. Morshuis and F. H. Kreuger, "The Influence of the Dielectric-gas Interface on the Discharge Mechanism in a Dielectric Bounded Cavity", 7 th Int. Symp. on HV Engineering, Dresden, pp. 127-130, 1991.

[62] P. H. F. Morshuis and F. H. Kreuger, "The Evolution of the Discharge Mechanism in a Dielectric Bounded Cavity due to Surface Effects", 3 rd Int. Conf. on Properties and Applications of Dielectric Materials, Tokyo, pp. 672-675, 1991.

[63] E. Gulski, Computer-aided recognition of partial discharges using statistical tools. PhD-thesis Delft University of Technology, Promotor: prof. dr. ir. F. H. Kreuger, Delft University Press, ISBN 906275-728-6, Delft, 1991.

[64] E. Gulski and F. H. Kreuger, "Computer-aided Recognition of Discharge Patterns", 7 th International Symposium on HV Engineering, Dresden, pp. 9-12, 1991.

[65] E. Gulski and F. H. Kreuger, "Recognition of Discharge Sources using Statistical Tools", 3 rd International Conference on Properties and Applications of Dielectric Materials, Tokyo, pp. 39-42, 1991.

[66] T. Jing, P. H. F. Morshuis and F. H. Kreuger, "Surface Charge Accumulation and Decay on a Spacer Stressed with dc Voltage at Atmospheric Conditions", Archiv für Elektrotechnik, Vol. 74, pp. 315-319, 1991.

[67] T. Jing, P. H. F. Morshuis and F. H. Kreuger, "Experimental determination of capacitive parameters for calibration of surface charge measurement." 7 th International Symposium on HV Engineering, Dresden, pp. 135-138, 1991.
[68] F. H. Kreuger, Industrial HV. 1. Fields. 2. Dielectrics. 3. Constructions, Delft University Press, ISBN 90-6275-561-5, Delft, 1991.

[69] F. H. Kreuger, Industrial HV. Vol. 2. 4. Coordinating 5. Testing 6. Measuring, Delft University Press, ISBN 90-6275-562-3, Delft, 1992.

[70] E. Gulski and F. H. Kreuger, "Computer-aided Recognition of Discharge Sources", IEEE Transactions on EI, Vol. 27, nr. 1, p. 82-92, 1992.

[71] E. Gulski and F. H. Kreuger, "Determination of Discharge Sources by Analysis of Discharge Quantities as a Function of Time", 1992 IEEE International Symposium on Electrical Insulation, Baltimore, IEEE ISBN 0-7803-0649-X, p. 397-400, 1992.

[72] E. Gulski and F. H. Kreuger, "Automatische Erkennung von Teilentladungs-störstellen Mittels Statistischer Operatoren", 5th Haefely Symposium, Stuttgart, p. 3. 10, 1992.

[73] E. Gulski and F. H. Kreuger, "Diagnostics of Insulating Systems using Statistical Tools", IEEE International Symposium on Electrical Insulation, Baltimore, IEEE ISBN 0- 7803-0649-X, pp. 393396, 1992.

[74] F. H. Kreuger, E. Gulski and W. A. Sonneveld, "Diagnosis in GIS by Statistical Analysis of Discharges", CIGRE International Conference on Large HV Electric systems, Paris, pp. 1-5, 1992.

[75] F. H. Kreuger, "Do Materials Exist?", Nordic Insulation Symposium, Västerås, Tapir ISSN 11024925, p. 1. 1-1. 12, 1992.

[76] P. H. F. Morshuis and F. H. Kreuger, "The Spatial Distribution and Electrical Parameters of Partial Discharges in Polyethylene Insulation during $\mathrm{Ag}$ ing", 4 th Int. Conf. on Conduction and Breakdown in Solid Dielectrics, Sestri Levante, pp. 209-214, 1992.

[77] P. H. F. Morshuis and F. H. Kreuger, "A Relation between Time-resolved Discharge Parameters and Aging", 6 th Int. Conf. on Dielectric Materials, Measurements and Applications, Manchester, pp. 37-40, 1992.

[78] T. Jing, Surface charge Accumulation in SF6. Mechanisms and effects. PhD-thesis, Delft University of Technology. Promotor: prof. dr. ir. F. H. Kreuger, Delft University Press. ISBN 90-6275848-7, Delft, 1993.

[79] P. H. F. Morshuis, Partial discharge mechanisms. Mechanisms leading to breakdown, analyzed by fast electrical and optical measurements. PhDthesis, Delft University of Technology, Promotor: 
prof. dr. ir. F. H. Kreuger, Delft University Press, ISBN 90-6275-931-9, Delft, 1993.

[80] F. H. Kreuger, E. Gulski and A. Krivda, "Classification of Partial Discharges", IEEE Transactions on EI, Vol. 28, nr. 6, pp. 917-931, 1993.

[81] F. H. Kreuger, "Vier Miljoen Volt Bliksemspanning", Energie Technologie, Vol. 3, nr. 11, pp. 4-6, 1993.

[82] F. H. Kreuger and U. Fromm, "Partial Discharges in Gaseous Voids for dc Voltage", Japanese Journal of Appl. Physics, Vol. 33, pp. 1079-1084, 1994.

[83] F. H. Kreuger and U. Fromm, "Time-resolved Measurements of Partial Discharges in Gaseous Voids at dc Voltages", Nordic Insulation Symposium, Vaasa, ISBN 952-90-5348-7, pp. 1. 1-1. 12, 1994.

[84] U. Fromm and F. H. Kreuger, "Statistical Behavior of Internal Partial Discharges at dc Voltage", Japanese Journal of Appl. Physics, Vol. 33, pp. 6708-6715, 1994.

[85] E. Gulski, P. H. F. Morshuis and F. H. Kreuger, "Conventional and Time-resolved Measurements of Partial Discharges as a Tool for Diagnosis of Materials", 4 th International Conference on Properties and Applications of Dielectric Materials, Brisbane, pp. 666-669, 1994.

[86] F. H. Kreuger, P. H. F. Morshuis and E. Gulski, "Evaluation of Discharge Damage by Fast Transient Detection and Statistical Analysis", CIGRE International Conference on Large HV Electric systems, Paris, paper 15-106, 1994.
[87] F. H. Kreuger, M. G. Wezelenburg, A. G. Wiemer and W. A. Sonneveld, "Errors in Location of Partial Discharges in HV Solid Dielectric Cables", IEEE Electrical Insulation Magazine, Vol. 9, No. 6, pp. 15-23, 1994.

[88] T. Jing,, P. H. F. Morshuis and F. H. Kreuger, "Mechanisms of Surface Charge Accumulation in Sf6", Archiv für Elektrotechnik, Vol. 77, pp. 151155, 1994.

[89] T. Jing,, P. H. F. Morshuis and F. H. Kreuger, "The Role of Space Charge Conditions in the Scatter of Charge Accumulation", 4 th International Conference on Properties and Applications of Dielectric Materials, Brisbane, pp. 274-277, 1994.

[90] F. H. Kreuger, Industrial High DC Voltage. Delft University Press, 1995.

[91] U. Fromm, Partial Discharge and Breakdown Testing at High $D C$ Voltage, $\mathrm{PhD}$-thesis, Delft University of Technology, Promotor: prof. dr. ir. F. H. Kreuger, Delft University Press, Delft, ISBN 90407-1155-0, 1995.

[92] A. Krivda, Recognition of Discharges, PhD-thesis, Delft University of Technology, Promotor: prof. dr. ir. F. H. Kreuger, Delft University Press, Delft, ISBN 90-407-1156-9, 1995.

[93] M. J. P. Jeroense and F. H. Kreuger, "Electrical Conduction in HVDC Mass-impregnated Paper Cable", IEEE Transactions on Dielectrics and EI, Vol. 2, pp. 718-723, 1995.

Manuscript was received on 11 September 1995. 